\title{
GABA in the Nucleus Accumbens Shell Participates in the Central Regulation of Feeding Behavior
}

\author{
Thomas R. Stratford and Ann E. Kelley \\ Department of Psychiatry, University of Wisconsin-Madison Medical School, Madison, Wisconsin 53719
}

We have demonstrated previously that injections of $6,7-$ dinitroquinoxaline-2,3-dione into the nucleus accumbens shell (AcbSh) elicits pronounced feeding in satiated rats. This glutamate antagonist blocks AMPA and kainate receptors and most likely increases food intake by disrupting a tonic excitatory input to the AcbSh, thus decreasing the firing rate of a population of local neurons. Because the application of GABA agonists also decreases neuronal activity, we hypothesized that administration of GABA agonists into the AcbSh would stimulate feeding in satiated rats. We found that acute inhibition of cells in the AcbSh via administration of the $\mathrm{GABA}_{A}$ receptor agonist muscimol or the $\mathrm{GABA}_{B}$ receptor agonist baclofen elicited intense, dose-related feeding without altering water intake. Muscimol-induced feeding was blocked by coadministration of the selective $\mathrm{GABA}_{\mathrm{A}}$ receptor blocker bicuculline, but not by the $\mathrm{GABA}_{\mathrm{B}}$ receptor blocker saclofen. Conversely, baclofen-induced feeding was blocked by coadministration of saclofen, but was not affected by bicuculline. Furthermore, we found that increasing local levels of GABA by administration of a selective GABA-transaminase inhibitor, $\gamma$-vinyl-GABA, elicited robust feeding in satiated rats, suggesting a physiological role for endogenous AcbSh GABA in the control of feeding. A mapping study showed that although some feeding can be elicited by muscimol injections near the lateral ventricles, the ventromedial AcbSh is the most sensitive site for eliciting feeding. These findings demonstrate that manipulation of GABAsensitive cells in the AcbSh can have a pronounced, but specific, effect on feeding behavior in rats. They also constitute the initial description of a novel and potentially important component of the central mechanisms controlling food intake.

Key words: GABA; food intake; nucleus accumbens shell; muscimol; baclofen; feeding behavior; $\gamma$-vinyl-GABA
The nucleus accumbens is a basal forebrain structure that is perhaps best known for being an important constituent of the neural systems mediating reward and reinforcement (Koob and Bloom, 1988; Salamone, 1996). Although the nucleus accumbens was viewed originally as a unitary structure, a convergent body of data indicates that it consists of at least two distinct components that can be differentiated in a number of ways. The relatively narrow band of tissue forming the medial and ventral borders of the classically identified accumbens has been termed the nucleus accumbens shell (AcbSh) (Zaborszky et al., 1985) and can be distinguished from the tissue immediately surrounding the anterior commissure, known as the nucleus accumbens core (AcbC), on the basis of histochemical (Voorn et al., 1989; Jongen-Relo et al., 1994), cytoarchitectonic (Meredith et al., 1992), and hodological (Heimer et al., 1991; Brog et al., 1993; Wright and Groenewegen, 1995) profiles. Further support for distinctive subregions is provided by evidence of differential changes in neurotransmitter release or metabolism (Deutch and Cameron, 1992; Ladurelle et al., 1994; Pontieri et al., 1995; Sorg et al., 1995; Jones et al., 1996), glucose utilization (Pontieri et al., 1994), and gene expression (Dilts et al., 1993; Beck and Fibiger, 1995; Chergui et al., 1996) in response to various stimuli. Therefore, it is not surprising that the AcbSh and AcbC also have been dissociated on the basis of differential behavioral responses to comparable manipulations

\footnotetext{
Received Jan. 16, 1997; revised March 10, 1997; accepted March 20, 1997.

This study was supported by research Grant DA04788 from the National Institute on Drug Abuse.

Correspondence should be addressed to Dr. Thomas R. Stratford, Department of Pharmacology, Allegheny University of the Health Sciences, 3200 Henry Avenue, Philadelphia, PA 19129.

Copyright (C) 1997 Society for Neuroscience $\quad 0270-6474 / 97 / 174434-07 \$ 05.00 / 0$
}

(Maldonado-Irizarry and Kelley, 1994; Pulvirenti et al., 1994; Johnson et al., 1995).

Although numerous studies have investigated the role of the nucleus accumbens in the control of food intake (Majeed et al., 1986; Wise et al., 1989; Fletcher, 1991a,b; Bakshi and Kelley, 1993a; Bodnar et al., 1995; Gilbert and Cooper, 1995; Sills and Vaccarino, 1996), they usually have been limited to the involvement of dopamine or opioids. Furthermore, because the distinction between the AcbSh and AcbC has been appreciated only recently, most studies of accumbens function that used intraaccumbens manipulations targeted the pericommissural center of the entire structure, which generally yields lesions or injection sites confined to the AcbC. Therefore, the relevance of much of the "accumbens" literature to specific AcbSh function is in question. Few studies have restricted injections of neuroactive compounds to the AcbSh, leaving the behavioral effects of pharmacological manipulations of this region relatively unknown.

Recent work in this laboratory has involved an attempt to elucidate the function of glutamate in the AcbSh. We have found that blockade of AMPA and kainate receptors in the AcbSh, but not the AcbC, elicits a strong feeding response in satiated rats (Maldonado-Irizarry et al., 1995). Blockade of AcbSh glutamate receptors most likely increases food intake by disrupting tonically active excitatory afferents, thus inhibiting a local population of neurons. The AcbSh contains a well characterized GABAergic system consisting primarily of medium-sized, spiny projection neurons (Meredith et al., 1993), and it is likely that inhibition of some subset of this neuronal population is the relevant cellular event leading to feeding. Because neuronal activity can also be inhibited by the application of GABA agonists, it is possible that injections of these compounds into the AcbSh would also stimu- 
late food intake. To test this hypothesis, feeding behavior was observed in satiated rats after microinjections of various direct and indirect GABA agonists into the AcbSh.

\section{MATERIALS AND METHODS}

Subjects. Male Sprague Dawley rats (Harlan Sprague Dawley, Indianapolis, IN) weighing between 280 and $300 \mathrm{gm}$ at the time of surgery were group-housed in acrylic cages and maintained in a temperaturecontrolled $\left(\sim 21^{\circ} \mathrm{C}\right)$ and light-controlled $(12 \mathrm{hr}$ light/dark) environment with food (Harlan Teklad Rat Diet 7001) and acidified tap water available ad libitum.

Surgery. The rats were anesthetized with a mixture of ketamine $\mathrm{HCl}$ and xylazine $(100 \mathrm{mg} / \mathrm{kg}$ and $10 \mathrm{mg} / \mathrm{kg}$, respectively) (Sigma, St. Louis, MO), and bilateral 23-gauge stainless steel guide cannulae were implanted using standard, flat-skull stereotaxic techniques (Paxinos and Watson, 1986). For each experimental group in Experiments 1-4, 8-10 rats received guide cannulae aimed at the AcbSh using the following coordinates: anteroposterior (AP), 1.4; lateral (L), \pm 0.8 ; dorsoventral (DV), $-5.5 \mathrm{~mm}$ from bregma. For Experiment 5, six rats were implanted with guide cannulae aimed at the AcbC (AP, $1.4 ; \mathrm{L}, \pm 2.0 ; \mathrm{DV},-5.2 \mathrm{~mm}$ from bregma), and five rats received guide cannulae aimed at the AcbSh using the same coordinates as in Experiments 1-4. Three other groups of five rats received guide cannulae placed $1.0 \mathrm{~mm}$ rostral (AP: 2.4), $1.0 \mathrm{~mm}$ caudal (AP: 0.4 ), or $2.0 \mathrm{~mm}$ caudal (AP: -0.6 ) to the standard placement. The guide cannulae were held in place with stainless steel screws and denture lining material, and a stainless steel obturator was inserted into the lumen of each cannula to help maintain patency. Each rat received a prophylactic intramuscular injection of sterile penicillin (Flo-Cillin; Fort Dodge Laboratories, Fort Dodge, IA) $(\sim 100,000 \mathrm{U})$ after surgery and was allowed to recover at least $7 \mathrm{~d}$ before the start of behavioral testing.

Intracerebral injections. To acclimate the rats to the test procedure, they were restrained, the obturators were removed, and a 30-gauge injection cannula, extending $2.5 \mathrm{~mm}$ beyond the ventral tip of the guide, was inserted into each guide cannula on 3 consecutive days. The obturators were replaced, and the rats were placed in the test cages for either 30 or $120 \mathrm{~min}$. On the final acclimation day, each rat received a $0.5 \mu \mathrm{l}$ intracerebral injection of $0.15 \mathrm{M}$ saline. On test days, each rat received simultaneous bilateral injections of $0.5 \mu \mathrm{l}$ of drug or the $0.15 \mathrm{~m}$ saline vehicle at a rate of $0.32 \mu \mathrm{l} / \mathrm{min}$. After the infusion, the injection cannulae were left in place for an additional $60 \mathrm{sec}$ to minimize leakage up the cannula track. At least $48 \mathrm{hr}$ were allowed between injections.

Drugs. Muscimol and baclofen were obtained from Sigma. All other drugs were obtained from Research Biochemicals International (Natick, MA). All drugs were dissolved in $0.15 \mathrm{~m}$ saline. Where group numbers permitted, drug doses were administered in a counterbalanced order. Where full counterbalancing was not possible, a semi-counterbalanced order was used, with individual exceptions noted below.

Experimental design. In Experiment 1 we examined the effects of intra-AcbSh infusions of equimolar doses of the $\mathrm{GABA}_{\mathrm{A}}$ agonist muscimol and the $G_{A B A}$ agonist baclofen on short-term food and water intake in satiated rats. One group of rats received bilateral injections of $0,10,20,50$, or $100 \mathrm{ng}(0,88,175,438$, or $876 \mathrm{pmol})$ of muscimol. The second group of rats received equimolar doses $(0,19,37,94$, or $188 \mathrm{ng})$ of baclofen. The rats were placed in test cages $(42 \times 20 \mathrm{~cm})$ with a preweighed quantity of food and a bottle containing tap water available. During the $30 \mathrm{~min}$ test, various behavioral parameters were recorded using a computer-based multi-channel event recording system (Paul Fray Ltd.). These behavioral measurements included latency to begin feeding, total time spent feeding, locomotor activity (as indicated by number of cage crossings), and total time spent rearing. At the end of the test, food intake (corrected for spillage) and water intake were calculated.

In Experiment 2 we attempted to determine whether the behavioral effects of muscimol and baclofen were being mediated solely through local $\mathrm{GABA}_{\mathrm{A}}$ and $\mathrm{GABA}_{\mathrm{B}}$ receptors, respectively. In this study, the feeding response of one group of rats was tested after injections of 0 or $50 \mathrm{ng}$ of muscimol. After each rat had been tested under the drug and vehicle conditions, it received injections a mixture of either $50 \mathrm{ng}$ of muscimol and $75 \mathrm{ng}$ of the specific $\mathrm{GABA}_{\mathrm{A}}$ receptor antagonist (-)bicuculline methylbromide or $50 \mathrm{ng}$ of muscimol and $500 \mathrm{ng}$ of the specific $\mathrm{GABA}_{\mathrm{B}}$ receptor antagonist saclofen. A second group of rats was tested in a similar fashion with $188 \mathrm{ng}$ of baclofen being substituted for the muscimol at each stage of testing. After the injections, the rats were placed in test cages containing a preweighed quantity of food and a graduated drinking tube containing tap water. At the end of the test, food intake (corrected for spillage) and water intake were calculated.
Experiment 3 was a study of the effects of various doses of muscimol on $2 \mathrm{hr}$ food and water intake. Rats in this group were tested after 0, 10, 20, 50,100 , or $200 \mathrm{ng}$ of muscimol. After the microinjections, the rats were placed in test cages with food and tap water available. Food intake (corrected for spillage) was calculated at 30, 60, and $120 \mathrm{~min}$. Total water intake was determined at the end of the 120 min test.

Because the preceding experiments all concerned the administration of exogenous GABA agonists, we sought to determine whether endogenous GABA played a role in the central control of feeding behavior. Experiment 4 examined this question by attempting to increase local levels of GABA through the administration of $( \pm)$-nipecotic acid, a GABA uptake inhibitor, or $( \pm)$ - $\gamma$-vinyl-GABA (GVG), a selective inhibitor of the metabolic enzyme GABA transaminase (GABA-T). In this experiment, rats received injections of either 0 or $20 \mu \mathrm{g}$ of GVG followed by an injection of $10 \mu \mathrm{g} \mathrm{GVG}$, and then an injection of $3 \mu \mathrm{g}$ of nipecotic acid. An interinjection interval of at least $96 \mathrm{hr}$ was allowed in this experiment, and behavioral testing was performed as described in Experiment 3.

The fifth experiment was designed to identify the most sensitive site in the medial basal forebrain for eliciting feeding with muscimol. One group of six rats was implanted with guide cannulae aimed at the AcbC and was tested as described in Experiment 1 after bilateral injections of the saline vehicle, $50 \mathrm{ng}$ of muscimol, or $94 \mathrm{ng}$ of baclofen. To determine the response gradient along the rostral-caudal axis, separate groups of rats were prepared with guide cannulae positioned at either our standard placement or $1 \mathrm{~mm}$ rostral, $1 \mathrm{~mm}$ caudal, or $2 \mathrm{~mm}$ caudal to it (as detailed under Surgery). The rats received injections of either 0 or $50 \mathrm{ng}$ of muscimol through injection cannulae terminating $1 \mathrm{~mm}$ below the guide. After this series of tests was completed, rats were given another series of tests with drugs injected through cannulae terminating $2.5 \mathrm{~mm}$ below the guide. Thus, rats in this study each received saline and muscimol injections at two sites, one $1.5 \mathrm{~mm}$ above the other. After each treatment, the rats were tested as described in Experiment 3.

Histology. After behavioral testing, all of the animals were anesthetized deeply with sodium pentobarbital and perfused transcardially with $50 \mathrm{ml}$ of a $0.15 \mathrm{~m}$ saline solution followed immediately by $500 \mathrm{ml}$ of a $10 \%$ buffered formalin solution. The brains were removed and stored in fixative for at least 1 week. The brains were then frozen, and $60 \mu \mathrm{m}$ coronal sections were taken throughout the extent of the AcbSh. The sections were stained with cresyl violet, and the injection sites were examined for placement accuracy and excessive damage. Data from rats with misplaced cannulae were not included in the analyses.

Statistical analyses. In Experiment 1, food and water intake and each of the behavioral parameters collected were analyzed using two-way ANOVA (drug $\times$ dose; ANOVA) with repeated measures on the dose factor. In addition to the overall analysis, the method of linear contrast was used to compare the effects of each dose of drug with the salineinjected control trial. In Experiment 3, data were analyzed across doses using a one-way ANOVA with repeated measures. Where an overall significant effect of dose was found, individual comparisons with the vehicle treatment were examined using Dunnett's method. Food and water intake data from Experiments 2 and 4 were analyzed the same way, with individual treatments being handled as levels for the sake of statistical analysis.

In Experiment 5, data from the AcbC group were analyzed using a repeated-measures one-factor ANOVA. Data from the remaining sites were analyzed with a one-factor ANOVA followed by planned comparisons of the saline and drug treatments at each site using a Bonferroni adjustment to determine significance.

\section{RESULTS \\ Experiment 1}

Bilateral activation of AcbSh $\mathrm{GABA}_{\mathrm{A}}$ receptors with muscimol significantly increased food intake at all doses above 88 pmol (probability values for individual comparisons are given in Fig. $1 a)$. Similarly, activation of $\mathrm{GABA}_{\mathrm{B}}$ receptors with baclofen significantly increased feeding at all doses tested (Fig. 1a). Equimolar doses of muscimol and baclofen were equipotent at eliciting feeding. All doses tested of both drugs significantly decreased latency to begin feeding and increased feeding duration without affecting water intake or locomotor activity (probability values for individual comparisons are given in Table 1). The amount of time 

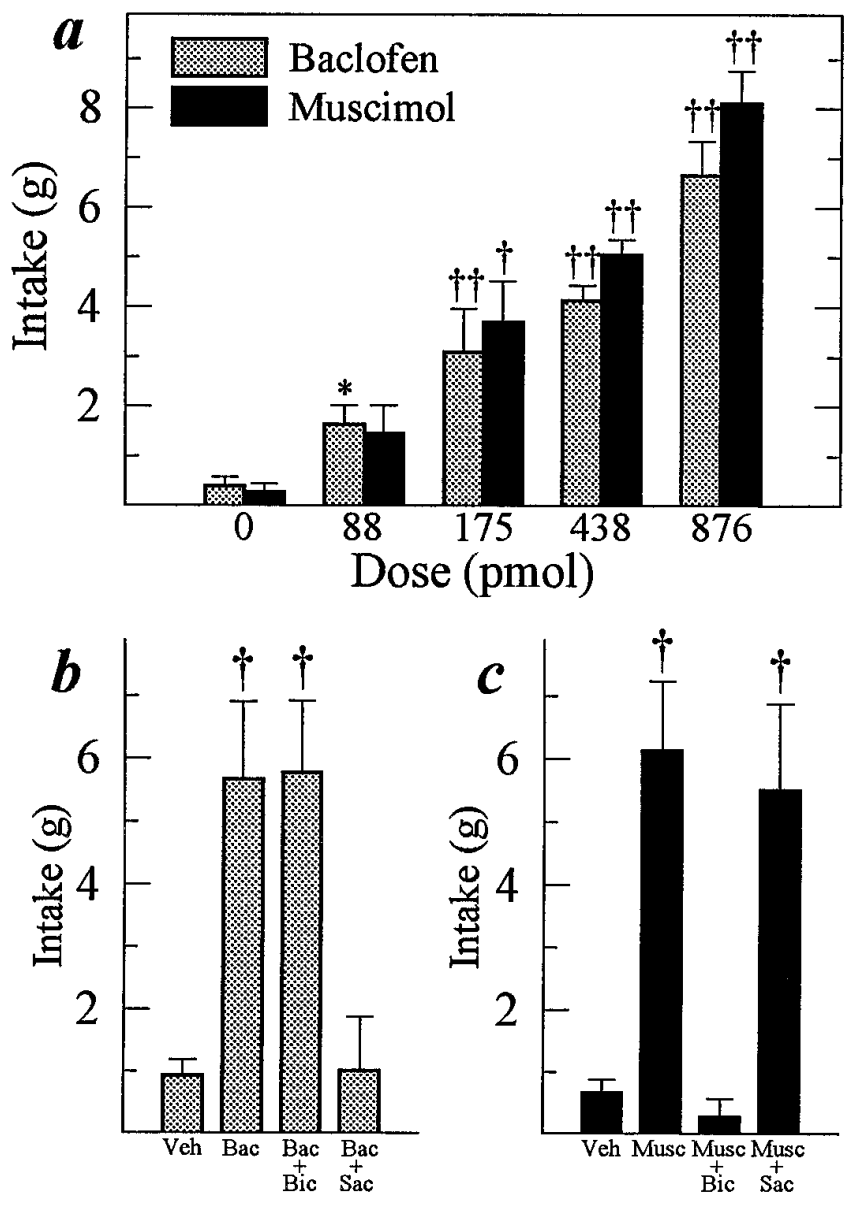

Figure 1. Mean $( \pm \mathrm{SEM}) 30 \mathrm{~min}$ food intake after bilateral microinjections of various doses of GABA agonists and antagonists into the AcbSh. $a$, Intake was increased significantly with all doses of baclofen tested and with all doses of muscimol over 88 pmol. $b$, As demonstrated in the previous experiment, injection of $188 \mathrm{ng}$ of baclofen significantly increased food intake $(p<0.01)$. The baclofen-induced feeding was eliminated by coadministration of $500 \mathrm{ng}$ of the selective $\mathrm{GABA}_{\mathrm{B}}$ antagonist saclofen, but was not affected by $75 \mathrm{ng}$ of the $\mathrm{GABA}_{\mathrm{A}}$ antagonist bicuculline. $c$, In a separate group of rats, $50 \mathrm{ng}$ of muscimol significantly increased food intake $(p<0.01)$, and this increase was abolished by coadministration of $75 \mathrm{ng}$ of bicuculline. Coadministration of $500 \mathrm{ng}$ saclofen had no effect on the feeding elicited by muscimol. Symbols denote significant increases in intake as compared with saline treatment. ${ }^{*} p<0.05 ; \dagger p<0.01$; $\ddagger p<0.001$.

spent rearing tended to be reduced at the higher doses of both drugs.

\section{Experiment 2}

As demonstrated in the previous experiment, $188 \mathrm{ng}$ of baclofen significantly increased food intake as compared with the saline treatment $(p<0.01$; Fig. $1 b)$. The baclofen-induced feeding was eliminated by coadministration of $500 \mathrm{ng}$ of the selective $\mathrm{GABA}_{\mathrm{B}}$ antagonist saclofen $(p<0.01)$, but was not affected by $75 \mathrm{ng}$ of the $\mathrm{GABA}_{\mathrm{A}}$ antagonist bicuculline methbromide. In a separate group of rats, injection of $50 \mathrm{ng}$ of muscimol significantly increased food intake $(p<0.01$; Fig. $1 c)$. This increase was abolished by coadministration of $75 \mathrm{ng}$ of bicuculline methbromide $(p<0.01)$. Coadministration of $500 \mathrm{ng}$ of saclofen had no effect on the feeding elicited by muscimol.

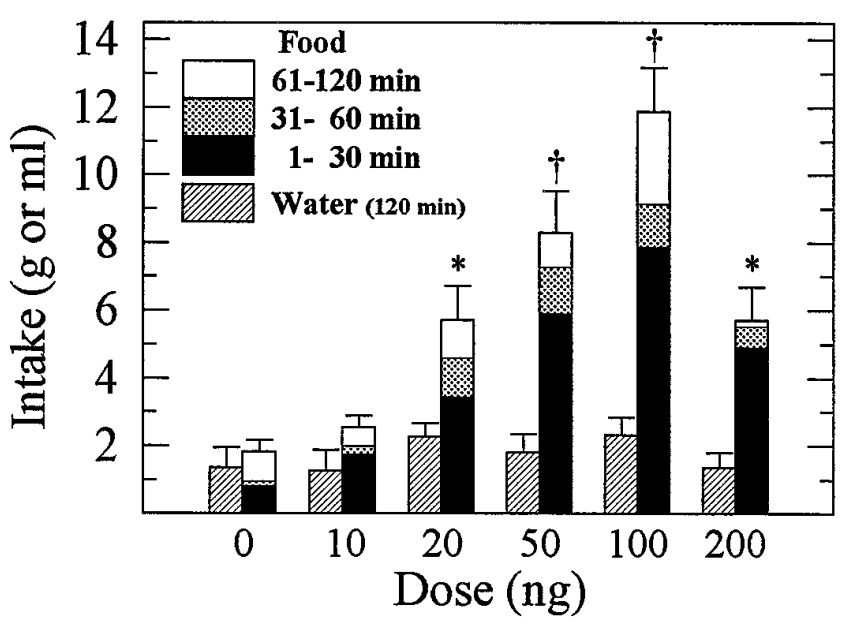

Figure 2. Mean ( \pm SEM) food and water intake after injection of various doses of muscimol into the AcbSh. Muscimol dose-dependently increased food intake at all doses $>10 \mathrm{ng}$, with $60-70 \%$ of the feeding occurring in the initial $30 \mathrm{~min}$. Muscimol had no effect on $120 \mathrm{~min}$ water intake at any dose. ${ }^{*} p<0.05 ; \dagger p<0.01$.

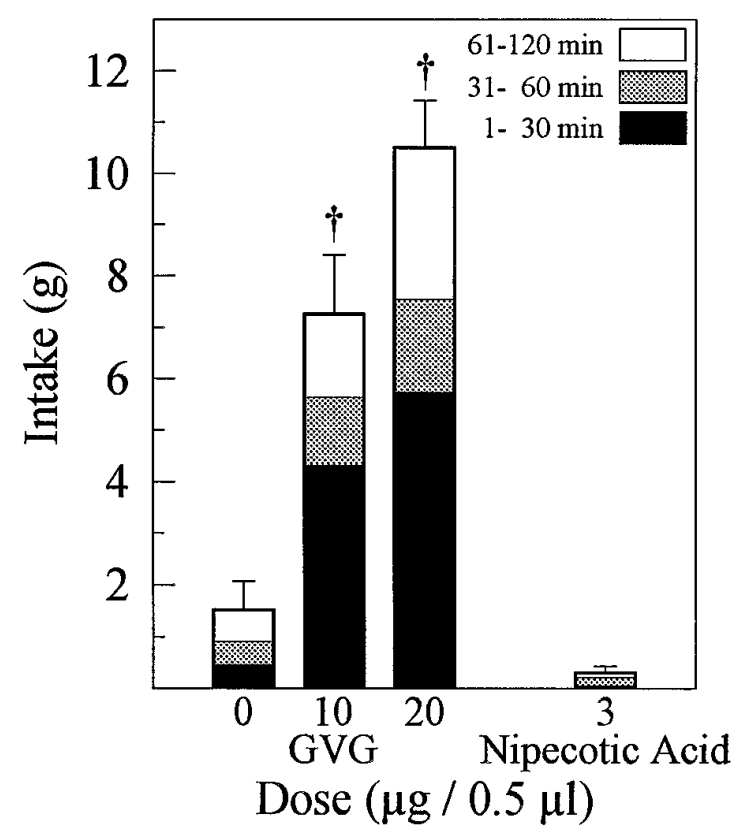

Figure 3. Mean ( \pm SEM) food intake after injections of the GABA-T inhibitor GVG or the GABA reuptake inhibitor nipecotic acid into the AcbSh. Although GVG significantly increased food intake at both doses tested $(\dagger p<0.01)$, nipecotic acid had no effect on feeding behavior.

\section{Experiment 3}

The overall effect of bilateral muscimol injections into the AcbSh on $2 \mathrm{hr}$ food intake was highly significant $\left(F_{(5,20)}=15.8 ; p<\right.$ $0.0001)$. Muscimol increased food intake in a dose-dependent manner with a maximal effect at $100 \mathrm{ng}$ (Fig. 2). Planned comparisons showed that the effect was significant at every dose above $10 \mathrm{ng}$; however, muscimol injections had no effect on water intake.

\section{Experiment 4}

Food intake was increased dramatically by bilateral injection of either 10 or $20 \mu \mathrm{g}$ of the specific GABA-T inhibitor GVG into the AcbSh $(p<0.01$ in both cases) (Fig. 3). Water intake was not 
Table 1. Behavioral parameters recorded (in addition to food intake illustrated in Figure 1a) during the 30 min subsequent to injections of various doses of baclofen or muscimol into the AcbSh

\begin{tabular}{|c|c|c|c|c|c|c|c|c|c|c|}
\hline & \multicolumn{5}{|c|}{ Baclofen (pmol) } & \multicolumn{5}{|c|}{ Muscimol (pmol) } \\
\hline & 0 & 88 & 175 & 438 & 876 & 0 & 88 & 175 & 438 & 876 \\
\hline $\begin{array}{l}\text { Latency to } \\
\text { feed (sec) }\end{array}$ & $\begin{array}{l}1212 \\
\pm 211\end{array}$ & $\begin{array}{l}106^{\dagger \dagger} \\
\pm 59\end{array}$ & $\begin{array}{l}509^{\dagger} \\
\pm 264\end{array}$ & $\begin{array}{l}78^{\dagger \dagger} \\
\pm 37\end{array}$ & $\begin{array}{l}152^{\dagger \dagger} \\
\pm 115\end{array}$ & $\begin{array}{l}1610 \\
\pm 110\end{array}$ & $\begin{array}{l}623^{\dagger} \\
\pm 229\end{array}$ & $\begin{array}{l}324^{\dagger \dagger} \\
\pm 140\end{array}$ & $\begin{array}{l}338^{\dagger \dagger} \\
\pm 143\end{array}$ & $\begin{array}{l}205^{\dagger \dagger} \\
\pm 121\end{array}$ \\
\hline $\begin{array}{l}\text { Feeding } \\
\quad \text { duration }(\mathrm{sec})\end{array}$ & $\begin{array}{l}65 \\
\pm 28\end{array}$ & $\begin{array}{l}409^{\dagger \dagger} \\
\pm 66\end{array}$ & $\begin{array}{l}410^{\dagger} \\
\pm 106\end{array}$ & $\begin{array}{l}622^{\dagger \dagger} \\
\pm 76\end{array}$ & $\begin{array}{l}895^{\dagger \dagger} \\
\pm 96\end{array}$ & $\begin{array}{l}32 \\
\pm 18\end{array}$ & $\begin{array}{l}265^{*} \\
\pm 98\end{array}$ & $\begin{array}{l}453^{\dagger \dagger} \\
\pm 65\end{array}$ & $\begin{array}{l}735^{\dagger \dagger} \\
\pm 65\end{array}$ & $\begin{array}{l}1295^{\dagger \dagger} \\
\pm 174\end{array}$ \\
\hline $\begin{array}{l}\text { Water } \\
\quad \text { intake }(\mathrm{ml})\end{array}$ & $\begin{array}{l}0.4 \\
\pm 0.2\end{array}$ & $\begin{array}{l}1.1 \\
\pm 0.6\end{array}$ & $\begin{array}{l}1.5 \\
\pm 0.6\end{array}$ & $\begin{array}{l}0.2 \\
\pm 0.2\end{array}$ & $\begin{array}{l}0.2 \\
\pm 0.1\end{array}$ & $\begin{array}{l}1.7 \\
\pm 0.5\end{array}$ & $\begin{array}{l}1.8 \\
\pm 0.7\end{array}$ & $\begin{array}{l}1.4 \\
\pm 0.6\end{array}$ & $\begin{array}{l}2.2 \\
\pm 0.8\end{array}$ & $\begin{array}{l}0.4 \\
\pm 0.4\end{array}$ \\
\hline $\begin{array}{l}\text { Locomotor } \\
\text { activity }\end{array}$ & $\begin{array}{l}30 \\
\pm 3.4\end{array}$ & $\begin{array}{l}32 \\
\pm 6.1\end{array}$ & $\begin{array}{l}22 \\
\pm 4.2\end{array}$ & $\begin{array}{l}29 \\
\pm 10.0\end{array}$ & $\begin{array}{l}18 \\
\pm 8.1\end{array}$ & $\begin{array}{l}22 \\
\pm 2.5\end{array}$ & $\begin{array}{l}19 \\
\pm 3.0\end{array}$ & $\begin{array}{l}21 \\
\pm 2.7\end{array}$ & $\begin{array}{l}21 \\
\pm 2.4\end{array}$ & $\begin{array}{l}24 \\
\pm 7.1\end{array}$ \\
\hline $\begin{array}{l}\text { Rearing } \\
\quad \text { duration (sec) }\end{array}$ & $\begin{array}{l}190 \\
\pm 36\end{array}$ & $\begin{array}{l}154 \\
\pm 17\end{array}$ & $\begin{array}{l}85^{\dagger} \\
\pm 16\end{array}$ & $\begin{array}{l}62^{\dagger} \\
\pm 24\end{array}$ & $\begin{array}{l}27^{\dagger \dagger} \\
\pm 11\end{array}$ & $\begin{array}{l}136 \\
\pm 28\end{array}$ & $\begin{array}{l}75 \\
\pm 18\end{array}$ & $\begin{array}{l}45^{*} \\
\pm 8\end{array}$ & $\begin{array}{l}57 \\
\pm 14\end{array}$ & $\begin{array}{l}37^{*} \\
\pm 21\end{array}$ \\
\hline
\end{tabular}

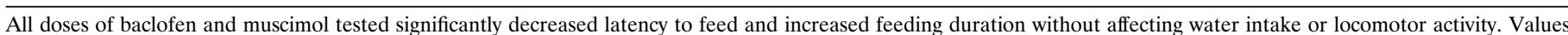
given are means \pm SEM. ${ }^{*} p<0.05 ;{ }^{\dagger} p<0.01 ;{ }^{\dagger \dagger} p<0.001$.

altered by either dose. Administration of $3 \mu \mathrm{g}$ of the GABA uptake inhibitor nipecotic acid did not affect food or water intake.

\section{Experiment 5}

Injections of muscimol or baclofen into the AcbC did not significantly affect food intake (30 min intake: saline, $0.2 \pm 0.08$; muscimol, $0.2 \pm 0.04$; baclofen, $0.9 \pm 0.50$ ). Although bilateral injections of muscimol into the AcbSh increased food intake significantly ( $p<0.001)$, injections rostral, dorsal, or caudal to this region did not significantly affect feeding behavior (Fig. 4). Injections dorsocaudal to the AcbSh that involved the lateral ventricles did increase food intake $(p<0.01)$, although the mean intake was approximately half as great as that seen after injections into the AcbSh. Water intake was not altered by muscimol injections into any of the sites.

\section{DISCUSSION}

The results obtained in this series of experiments demonstrate that manipulations of the AcbSh GABAergic system can have profound, but specific, effects on feeding behavior in rats. This system has not been described previously and is potentially an important component of the central mechanisms controlling food intake.

We have demonstrated that activation of either $\mathrm{GABA}_{\mathrm{A}}$ or $\mathrm{GABA}_{\mathrm{B}}$ receptors is sufficient to increase food intake. Furthermore, equimolar doses of the two GABA agonists are equipotent at increasing food intake (Fig. 1a), and the behavioral profile for animals receiving muscimol or baclofen is similar (Table 1). After either treatment, rats show a dose-dependent increase in food intake, with a corresponding decrease in latency to begin feeding. GABA agonists seem to act selectively on a feeding system, because they do not significantly alter water intake or locomotor activity. There is a tendency, however, for rearing duration to be decreased, especially after administration of high doses of baclofen or muscimol. Rearing behavior is often used as an index of exploratory activity, and this is most likely a concomitant of the large increase in the proportion of time the animal spends either feeding or in a period of post-ingestive quiescence.

Although not investigated in the AcbSh, baclofen has been shown to inhibit glutamate release in the AcbC (Uchimura and North, 1991). Furthermore, it has been demonstrated that in striatal spiny neurons (similar to those comprising the primary population of efferent neurons found in the AcbSh), activation of
$\mathrm{GABA}_{\mathrm{B}}$ receptors with baclofen will depress stimulation-induced excitatory postsynaptic potentials without affecting resting membrane potential, again indicating a presynaptic $\mathrm{GABA}_{\mathrm{B}}$-mediated inhibition of glutamate release (Nisenbaum et al., 1992, 1993). Application of muscimol does hyperpolarize these neurons, however, suggesting that although $\mathrm{GABA}_{\mathrm{A}}$ receptors are located on the dendrites and perikarya of striatal spiny neurons, functional $\mathrm{GABA}_{\mathrm{B}}$ receptors are limited to the presynaptic terminals. Thus, it seems likely that muscimol elicits an increase in food intake via a direct inhibition of a population of AcbSh neurons, whereas baclofen does so via a presynaptic inhibition of glutamate release.

Further evidence that muscimol and baclofen are acting exclusively through activation of $\mathrm{GABA}_{\mathrm{A}}$ and $\mathrm{GABA}_{\mathrm{B}}$ receptors, respectively, was obtained by the coadministration of receptorselective GABA antagonists. Feeding elicited by muscimol injections was completely suppressed by coadministration of $75 \mathrm{ng}$ of the $\mathrm{GABA}_{\mathrm{A}}$ receptor antagonist bicuculline, but was not affected by $500 \mathrm{ng}$ of the $\mathrm{GABA}_{\mathrm{B}}$ antagonist saclofen (Fig. 1c). Conversely, baclofen-induced feeding was eliminated by coadministration of saclofen, but was unaffected by bicuculline (Fig. 1b). Pilot studies showed that coadministration of $50 \mathrm{ng}$ of muscimol and doses of bicuculline $>100 \mathrm{ng}$ often precipitated seizures in our rats. These were not apparent with the $75 \mathrm{ng}$ dose of bicuculline used in this experiment, and the fact that baclofen-induced feeding was not affected by coadministration of this dose of bicuculline suggests that the rats were not nonspecifically impaired to any significant degree and were still fully capable of normal ingestion. No seizure activity or other abnormal behavior was observed after coadministration of saclofen.

The feeding elicited by microinjections of muscimol into the AcbSh was dose-related and relatively long lasting (Fig. 2). Two hour food intake was significantly increased at every dose $>10 \mathrm{ng}$, with $100 \mathrm{ng}$ eliciting the largest increase. With each dose of muscimol tested, $60-70 \%$ of the food was consumed during the initial $30 \mathrm{~min}$ of the test. Intake was not as great after $200 \mathrm{ng}$ of muscimol, but this was attributable largely to a reduction in the amount of feeding performed during the second hour of the test. This may suggest that the muscimol was diffusing to a site mediating a competing behavior and that expression of this behavior during the second hour of the test interfered with the feeding.

It seems that endogenous GABA in the AcbSh plays a role in the regulation of food intake. Microinjections of the GABA-T 


\section{Stereotaxic Coordinates (mm from bregma)}

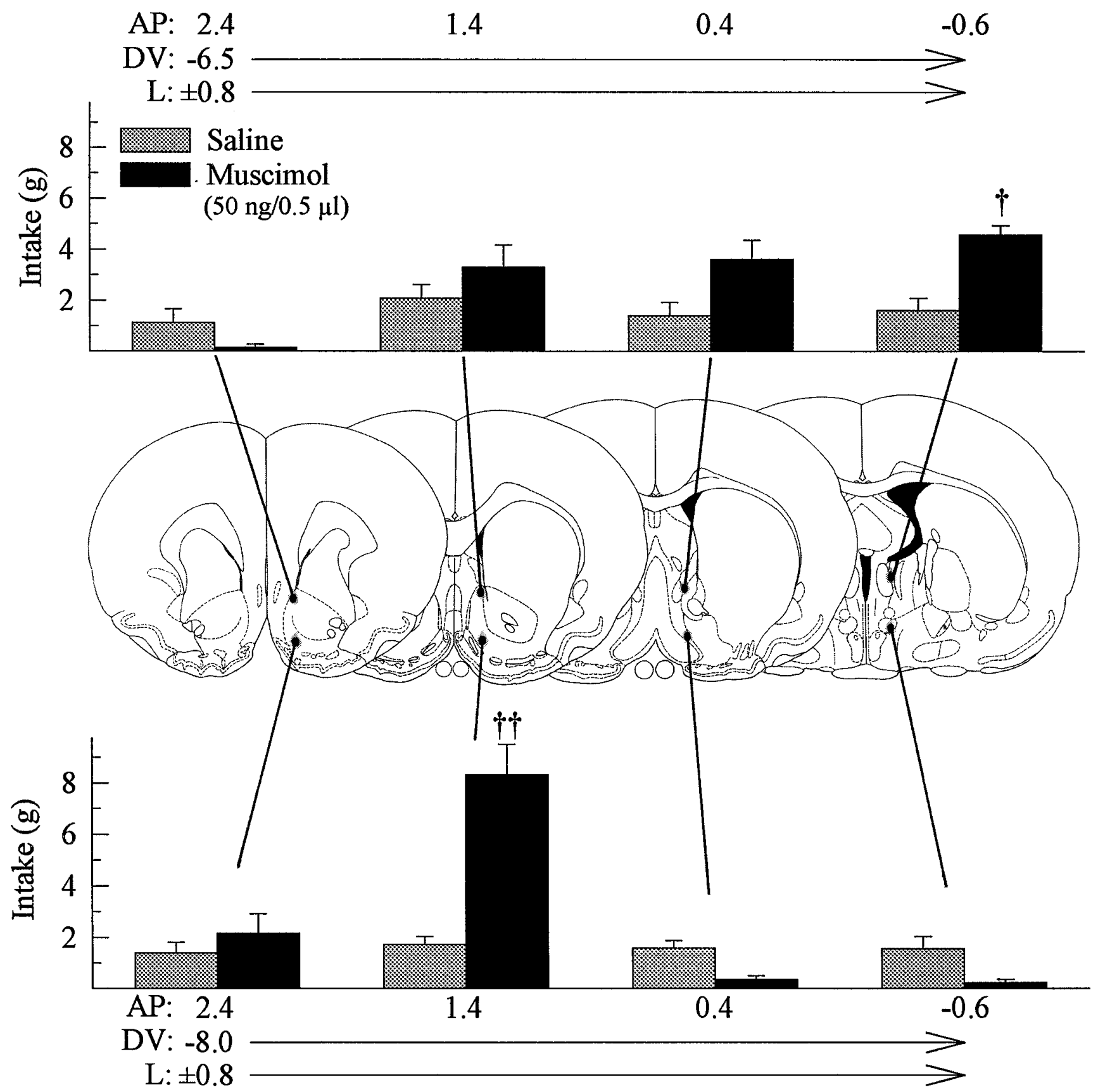

Figure 4. Mean $( \pm$ SEM) food intake after injections of saline or $50 \mathrm{ng}$ of muscimol into the AcbSh and several surrounding sites. Although muscimol injections near the lateral ventricles increased food intake, the ventromedial AcbSh was the most sensitive site for eliciting feeding. $\dagger p<0.01 ; \ddagger p<0.001$.

inhibitor GVG elicited intense, dose-related feeding (Fig. 3). By blocking the metabolism of GABA, this pharmacological intervention increases levels of endogenous GABA (Halonen et al., 1991) (although probably to supraphysiological levels). The fact that feeding was induced by inhibiting GABA metabolism suggests that there is a certain GABA tone in the AcbSh maintained, in part, by GABA-T in satiated rats. Interestingly, administration of the GABA reuptake blocker nipecotic acid did not affect food intake. Although the single dose tested $(3 \mu \mathrm{g})$ is higher than that shown to be necessary to elicit behavioral effects when injected into the ventral forebrain (Yang and Mogenson, 1987), it is possible that it falls outside the dose range that is required to elicit behavioral effects in this system. Alternatively, it may suggest that reuptake of GABA into the presynaptic terminal does not play a major role in deactivating GABA in this system. Rather, it seems that this may be the domain of GABA-T.

Food intake was not affected by injections of GABA agonists into the AcbC. Instead, the ventromedial AcbSh was the most 
sensitive site tested for eliciting feeding behavior with injections of muscimol (Fig. 4). Although injections placed immediately rostral, lateral, or caudal to this region did not affect food intake, there was a trend for injections near the ventricles to increase feeding that became significant with the most caudal placement. Intracerebroventricular administration of muscimol has been reported previously to increase food intake (Olgiati et al., 1980; Morley et al., 1981) and suggests the involvement of a paraventricular structure, possibly the ventromedial hypothalamic nucleus, in the expression of some GABA-mediated feeding syndromes. The fact that food intake was not increased by injections dorsal to the AcbSh, a site that involved the rostral aspect of the lateral ventricle, demonstrates that the primary locus of action in the present study is the ventromedial AcbSh. Furthermore, this conclusion is supported by the observation that the maximal increase in food intake observed after injections near the ventricles was less than half that seen after injections into the AcbSh.

Although the ventromedial AcbSh proved to be the most sensitive site tested for eliciting feeding, little can be said regarding the distribution of this system throughout the AcbSh. The dorsal and lateral poles of the AcbSh remain uninvestigated, and injections involving the rostral aspect of the AcbSh did not increase food intake, suggesting that the relevant cells may be distributed heterogeneously within this nucleus. A further caveat deserves mention. Embedded in the ventromedial AcbSh are other neuronal structures, most notably the islands of Calleja and rostral extensions of the ventral pallidum. Although our injections involved primarily the AcbSh, the possibility that one of these other structures plays a role in the mediation of feeding behavior by GABA agonists cannot be discounted.

Our results suggest strongly that food intake is regulated, in part, by a population of neurons located in the ventromedial AcbSh and that inhibition of these neurons is the cellular event that leads to the observed feeding response. These neurons are probably GABAergic, medium-sized, spiny projection neurons. On the basis of data obtained in a previous study showing that feeding can be induced by blocking AMPA and kainate receptors in this region (Maldonado-Irizarry et al., 1995), we propose that these neurons are chronically activated by glutamatergic afferents in satiated animals. These neurons can be hyperpolarized in a number of ways, including (1) activation of membrane $\mathrm{GABA}_{\mathrm{A}}$ receptors with muscimol, (2) an increase in local levels of GABA with GVG, (3) presynaptic inhibition of glutamate release via activation of $\mathrm{GABA}_{\mathrm{B}}$ receptors with baclofen, or (4) disruption of glutamate transmission from the excitatory afferents with AMPA/ kainate receptor blockers. All of these manipulations lead to an intense feeding response. At this point it is difficult to say what AcbSh projections may be relevant to this feeding system. The AcbSh receives afferent projections from a number of cortical and subcortical regions that have been implicated previously in the control of ingestive behavior. Among these are the infralimbic and piriform cortices, basolateral amygdala, ventral pallidum, lateral septum, lateral hypothalamus, ventral tegmental area, dorsal and median raphe nuclei, medial and lateral parabrachial nuclei, and nucleus of the solitary tract (Brog et al., 1993; Churchill and Kalivas, 1994; Wright and Groenewegen, 1995). Similarly, neurons in the AcbSh project to a number of brain regions that have been associated with the control of feeding behavior, including the ventral pallidum, centromedial amygdala, lateral hypothalamus, ventral tegmental area, and median raphe nucleus (Heimer et al., 1991). After inhibition of GABAergic AcbSh projection neurons by any of the aforementioned methods, the immediately subse- quent postsynaptic event should be a disinhibition of neurons located in terminal fields of this projection. Although we have not yet identified the relevant projections, we have some data suggesting the involvement of the lateral hypothalamus. We have demonstrated previously that injections of muscimol into the lateral hypothalamus can suppress the feeding induced by blockade of AcbSh AMPA and kainate receptors (Maldonado-Irizarry et al., 1995). In addition, we have found recently that simultaneous blockade of lateral hypothalamic NMDA receptors blocks feeding induced by muscimol injections into the AcbSh (unpublished observations). These results indicate that activation of neurons in the lateral hypothalamus is necessary for the expression of AcbSh-mediated feeding. Whether this involves the immediate control of lateral hypothalamic neurons by a direct or an indirect AcbSh projection remains to be seen.

It is interesting to consider the present findings in relation to other functional attributes of the nucleus accumbens. Traditionally, the nucleus accumbens has been considered a structure that plays a key role in central reinforcement and reward mechanisms. It is well established that this region subserves the reinforcing effects of self-administered drugs (Roberts et al., 1980; Hoebel et al., 1983; Vaccarino et al., 1985), and activation of opiate or dopamine receptors in the accumbens results in positive place conditioning (Van der Kooy et al., 1982; Carr and White, 1983). Moreover, many studies have suggested that both dopamine and opioid peptides in the accumbens are associated with feeding behavior and the incentive-motivational properties of food (Heffner et al., 1980; Hernandez and Hoebel, 1988; Blackburn et al., 1989; Bakshi and Kelley, 1993b; Salamone et al., 1994; Wilson et al., 1995). The finding that a restricted subregion of the nucleus accumbens plays a specific role in the control of a basic motivational state critical for survival lends support to the notion that the accumbens subserves reward and appetitive behavior.

In summary, our results indicate that GABA-sensitive neurons located in the ventromedial AcbSh have the ability to mediate feeding behavior in rats. Furthermore, we have shown that an increase in levels of endogenous GABA in the AcbSh induces feeding, suggesting that this system may participate in the physiological regulation of food intake. The magnitude and behavioral specificity of these effects suggest that the AcbSh is potentially an important component of the neural systems controlling feeding behavior in the rat.

\section{REFERENCES}

Bakshi VP, Kelley AE (1993a) Feeding induced by opioid stimulation of the ventral striatum: role of opiate receptor subtypes. J Pharmacol Exp Ther 265:1253-1260.

Bakshi VP, Kelley AE (1993b) Striatal regulation of morphine-induced hyperphagia: an anatomical mapping study. Psychopharmacology 111:207-214.

Beck CH, Fibiger HC (1995) Conditioned fear-induced changes in behavior and in the expression of the immediate early gene c-fos: with and without diazepam pretreatment. J Neurosci 15:709-720.

Blackburn JR, Phillips AG, Jakubovic A, Fibiger HC (1989) Dopamine and preparatory behavior. II. A neurochemical analysis. Behav Neurosci 103:15-23.

Bodnar RJ, Glass MJ, Ragnauth A, Cooper ML (1995) General, $\mu$ and k opioid antagonists in the nucleus accumbens alter food intake under deprivation, glucoprivic and palatable conditions. Brain Res 700:205-212.

Brog JS, Salyapongse A, Deutch AY, Zahm DS (1993) The patterns of afferent innervation of the core and shell in the "accumbens" part of the rat ventral striatum: immunohistochemical detection of retrogradely transported Fluoro-gold. J Comp Neurol 338:255-278.

Carr GD, White NM (1983) Conditioned place preference from intra- 
accumbens but not intra-caudate amphetamine injections. Life Sci 33:2551-2557.

Chergui K, Nomikos GG, Mathe JM, Gonon F, Svensson TH (1996) Burst stimulation of the medial forebrain bundle selectively increases Fos-like immunoreactivity in the limbic forebrain of the rat. Neuroscience 72:141-156.

Churchill L, Kalivas PW (1994) A topographically organized gammaaminobutyric acid projection from the ventral pallidum to the nucleus accumbens in the rat. J Comp Neurol 345:579-595.

Deutch AY, Cameron DS (1992) Pharmacological characterization of dopamine systems in the nucleus accumbens core and shell. Neuroscience 46:49-56.

Dilts Jr RP, Helton TE, McGinty JF (1993) Selective induction of Fos and FRA immunoreactivity within the mesolimbic and mesostriatal dopamine terminal fields. Synapse 13:251-263.

Fletcher PJ (1991a) Dopamine receptor blockade in nucleus accumbens or caudate nucleus differentially affects feeding induced by $8-\mathrm{OH}$ DPAT injected into dorsal or median raphe. Brain Res 552:181-189.

Fletcher PJ (1991b) Opiate antagonists inhibit feeding induced by 8-OHDPAT: possible mediation in the nucleus accumbens. Brain Res 560:260-267.

Gilbert DB, Cooper SJ (1995) 7-OH-DPAT injected into the accumbens reduces locomotion and sucrose ingestion: D3 autoreceptor-mediated effects? Pharmacol Biochem Behav 52:275-280.

Halonen T, Pitkanen A, Saano V, Riekkinen PJ (1991) Effects of vigabatrin $(\beta$-receptors of glutamatergic excitation and GABAergic inhibition of neostriatal neurons. J Neurophysiol 67:477-481.

Heffner TG, Hartman JA, Seiden LS (1980) Feeding increases dopamine metabolism in the rat brain. Science 208:1168-1170.

Heimer L, Zahm DS, Churchill L, Kalivas PW, Wohltmann C (1991) Specificity in the projection patterns of accumbal core and shell in the rat. Neuroscience 41:89-125.

Hernandez L, Hoebel BG (1988) Feeding and hypothalamic stimulation increase dopamine turnover in the accumbens. Physiol Behav 44:599-606.

Hoebel BG, Monaco AP, Hernandez L, Aulisi EF, Stanley BG, Lenard L (1983) Self-injection of amphetamine directly into the brain. Psychopharmacology 81:158-163.

Johnson PI, Goodman JB, Condon R, Stellar JR (1995) Reward shifts and motor responses following microinjections of opiate-specific agonists into either the core or shell of the nucleus accumbens. Psychopharmacology 120:195-202.

Jones SR, Odell SJ, Marshall JF, Wightman RM (1996) Functional and anatomical evidence for different dopamine dynamics in the core and shell of the nucleus accumbens in slices of rat brain. Synapse 23: $224-231$.

Jongen-Relo AL, Voorn P, Groenewegen HJ (1994) Immunohistochemical characterization of the shell and core territories of the nucleus accumbens in the rat. Eur J Neurosci 6:1255-1264.

Koob GF, Bloom FE (1988) Cellular and molecular mechanisms of drug dependence. Science 242:715-723.

Ladurelle N, Durieux C, Rofques BP, Dauge V (1994) Different modifications of the dopamine metabolism in the core and shell parts of the nucleus accumbens following CCK-A receptor stimulation in the shell region. Neurosci Lett 178:5-10.

Majeed NH, Przewlocka B, Wedzony K, Przewlocki R (1986) Stimulation of food intake following opioid microinjection into the nucleus accumbens septi in rats. Peptides 7:711-716.

Maldonado-Irizarry CS, Kelley AE (1994) Differential behavioral effects following microinjection of an NMDA antagonist into nucleus accumbens subregions. Psychopharmacology 116:65-72.

Maldonado-Irizarry CS, Swanson CJ, Kelley AE (1995) Glutamate receptors in the nucleus accumbens shell control feeding behavior via the lateral hypothalamus. J Neurosci 15:6779-6788.

Meredith GE, Agolia R, Arts MP, Groenewegen HJ, Zahm DS (1992) Morphological differences between projection neurons of the core and shell in the nucleus accumbens of the rat. Neuroscience 50:149-162.

Meredith GE, Pennartz CM, Groenewegen HJ (1993) The cellular framework for chemical signalling in the nucleus accumbens. Prog Brain Res 99:3-24.
Morley JE, Levine AS, Kneip J (1981) Muscimol induced feeding: a model to study the hypothalamic regulation of appetite. Life Sci 29:1213-1218.

Nisenbaum ES, Berger TW, Grace AA (1993) Depression of glutamatergic and GABAergic synaptic responses in striatal spiny neurons by stimulation of presynaptic $\mathrm{GABA}_{\mathrm{B}}$ receptors. Synapse 14:221-242.

Olgiati VR, Netti C, Guidobono F, Pecile A (1980) The central GABAergic system and control of food intake under different experi mental conditions. Psychopharmacology 68:163-167.

Paxinos G, Watson C (1986) The rat brain in stereotaxic coordinates, 2nd Ed. Sydney: Academic.

Pontieri FE, Colangelo V, La Riccia M, Pozzilli C, Passarelli F, Orzi F (1994) Psychostimulant drugs increase glucose utilization in the shell of the rat nucleus accumbens. NeuroReport 5:2561-2564.

Pontieri FE, Tanda G, Di Chiara G (1995) Intravenous cocaine, morphine, and amphetamine preferentially increase extracellular dopamine in the "shell" as compared with the "core" of the rat nucleus accumbens. Proc Natl Acad Sci USA 92:12304-12308.

Pulvirenti L, Berrier R, Kreifeldt M, Koob GF (1994) Modulation of locomotor activity by NMDA receptors in the nucleus accumbens core and shell regions of the rat. Brain Res 664:231-236.

Roberts DC, Koob GF, Klonoff P, Fibiger HC (1980) Extinction and recovery of cocaine self-administration following 6-hydroxydopamine lesions of the nucleus accumbens. Pharmacol Biochem Behav 12:781-787.

Salamone JD (1996) The behavioral neurochemistry of motivation: methodological and conceptual issues in studies of the dynamic activity of nucleus accumbens dopamine. J Neurosci Methods 64:137-149.

Salamone JD, Cousins MS, McCullough LD, Carriero DL, Berkowitz RJ (1994) Nucleus accumbens dopamine release increases during instrumental lever pressing for food but not free food consumption. Pharmacol Biochem Behav 49:25-31.

Sills TL, Vaccarino FJ (1996) Individual differences in sugar consumption following systemic or intraaccumbens administration of low doses of amphetamine in nondeprived rats. Pharmacol Biochem Behav 54:665-670.

Sorg BA, Guminski BJM, Hooks MS, Kalivas PW (1995) Cocaine alters glutamic acid decarboxylase differentially in the nucleus accumbens core and shell. Mol Brain Res 29:381-386.

Uchimura N, North RA (1991) Baclofen and adenosine inhibit synaptic potentials mediated by gamma-aminobutyric acid and glutamate release in rat nucleus accumbens. J Pharmacol Exp Ther 258:663-668.

Vaccarino FJ, Bloom FE, Koob GF (1985) Blockade of nucleus accumbens opiate receptors attenuates intravenous heroin reward in the rat. Psychopharmacology 86:37-42.

Van der Kooy D, Mucha RF, O’Shaughnessy M, Bucenieks P (1982) Reinforcing effects of brain microinjections of morphine revealed by conditioned place preference. Brain Res 243:107-117.

Voorn P, Gerfen CR, Groenewegen HJ (1989) Compartmental organization of the ventral striatum of the rat: immunohistochemical distribution of enkephalin, substance $\mathrm{P}$, dopamine, and calcium-binding protein. J Comp Neurol 289:189-201.

Wilson C, Nomikos GG, Collu M, Fibiger HC (1995) Dopaminergic correlates of motivated behavior: importance of drive. J Neurosci 15:5169-5178.

Wise RA, Fotuhi M, Colle LM (1989) Facilitation of feeding by nucleus accumbens amphetamine injections: latency and speed measures. Pharmacol Biochem Behav 32:769-772.

Wright CI, Groenewegen HJ (1995) Patterns of convergence and segregation in the medial nucleus accumbens of the rat: relationships of prefrontal cortical, midline thalamic, and basal amygdaloid afferents. J Comp Neurol 361:383-403.

Yang CR, Mogenson GJ (1987) Hippocampal signal transmission to the pedunculopontine nucleus and its regulation by dopamine D2 receptors in the nucleus accumbens: an electrophysiological and behavioural study. Neuroscience 23:1041-1055.

Zaborszky L, Alheid GF, Beinfeld MC, Eiden LE, Heimer L, Palkovits M (1985) Cholecystokinin innervation of the ventral striatum: a morphological and radioimmunological study. Neuroscience 14:427-453. 